NBER WORKING PAPER SERIES

\title{
THE EFFECTS OF CHANGES IN WOMEN'S LABOR MARKET ATTACHMENT ON REDISTRIBUTION UNDER THE SOCIAL SECURITY BENEFIT FORMULA
}

\author{
Alan L. Gustman \\ Thomas L. Steinmeier \\ Nahid Tabatabai \\ Working Paper 17439 \\ http://www.nber.org/papers/w17439
}
NATIONAL BUREAU OF ECONOMIC RESEARCH
1050 Massachusetts Avenue
Cambridge, MA 02138
September 2011

This research was supported by a grant from the U.S. Social Security Administration (SSA) through the Michigan Retirement Research Center (MRRC) under grant number UM11-06. The findings and conclusions expressed are solely those of the authors and do not represent the views of SSA or the MRRC. David Olson of the Social Security Administration was extremely helpful to us in dealing with the ANYPIA program. We also thank Mike Hurd, Olivia Mitchell and participants at the MRRC workshop for their helpful comments. The views expressed herein are those of the authors and do not necessarily reflect the views of the National Bureau of Economic Research.

(C) 2011 by Alan L. Gustman, Thomas L. Steinmeier, and Nahid Tabatabai. All rights reserved. Short sections of text, not to exceed two paragraphs, may be quoted without explicit permission provided that full credit, including $(\mathrm{C}$ notice, is given to the source. 
The Effects of Changes in Women's Labor Market Attachment on Redistribution Under the Social Security Benefit Formula

Alan L. Gustman, Thomas L. Steinmeier, and Nahid Tabatabai

NBER Working Paper No. 17439

September 2011

JEL No. D31,H55,J11,J14,J16,J18,J26,J38

\begin{abstract}
Studies using data from the early 1990s suggested that while the progressive Social Security benefit formula succeeded in redistributing benefits from individuals with high earnings to individuals with low earnings, it was much less successful in redistributing benefits from households with high earnings to households with low earnings. Wives often earned much less than their husbands. As a result, much of the redistribution at the individual level was effectively from high earning husbands to their own lower earning wives. In addition, spouse and survivor benefits accrue disproportionately to women from high income households. Both factors mitigate redistribution at the household level.

This paper compares outcomes for the earlier cohort with those of a cohort born twelve years later. The aim of the study is to see whether, after the recent growth in two earner households, and the growth in women's labor market activity and earnings, the Social Security system now fosters somewhat more redistribution from high to low earning households. The analysis is based on data from the Health and Retirement Study and includes members of households with at least one person age 51 to 56 in either 1992 or in 2004.
\end{abstract}

As expected, women enjoyed a more rapid growth of labor force participation, hours of work and covered earnings than men. This increased the redistribution of Social Security benefits among households. Nevertheless, a considerable gap remains between the labor market activities and earnings of women versus men. As a result, the Social Security system remains much less successful in redistributing benefits from households with high covered earnings to those with lower covered earnings than in redistributing benefits from individuals with high covered earnings to those with lower covered earnings.

Alan L. Gustman

Department of Economics

Dartmouth College

Hanover, NH 03755-3514

and NBER

AODQL.GXWI DO@ GDWA RXWTHX

Thomas L. Steinmeier

Department of Economics

Texas Tech University

Lubbock, TX 79409

thomas.steinmeier@ttu.edu
Nahid Tabatabai

Department of Economics

Dartmouth College

Hanover, N.H. 03755

Nahid.Tabatabai@dartmouth.edu 
The Social Security benefit formula is designed to redistribute old age benefits in favor of individuals with low lifetime earnings. Studies using data from the early 1990s for individuals approaching retirement age found the Social Security old age and survivors program did meet that goal. However, Social Security was much less successful in redistributing benefits to families with low lifetime earnings. Three studies (Coronado, Fullerton and Glass, 2000; Gustman and Steinmeier, 2001; Liebman, 2002) conducted at roughly the same time on three different data sets found that, when lifetime benefit payments to households were weighed against taxes paid, there was surprisingly little redistribution fostered by Social Security old age and survivor benefits -- from families with high lifetime earnings to families with low lifetime earnings. ${ }^{2}$

Since 1992, the labor force participation rate and fraction of women working full time has increased. As women's earnings increase, the relative value of their spouse and survivor benefits decline, and they benefit less from the redistributive structure of the benefit formula. Thus we expect that, at the family level, Social Security has become more redistributive over time. The question is, how much more redistributive has it become? This study estimates the

\footnotetext{
${ }^{2}$ A study conducted by Harris and Sabelhaus (2005) for the Congressional Budget Office, using a CBO dynamic simulation model (CBOLT), concluded there was a significant amount of redistribution among families with different earnings levels. This conclusion was not strongly influenced by differences in mortality rates by those with different lifetime earnings, and held for the sample of households whether or not it included households where one of the members qualified for disability benefits. Hurd (2011) discusses the differences between the CBO results and those in other studies, including the three noted above, as well as Goda, Shoven and Slalov (2011), which is similar in approach to the three earlier studies. He concludes that there are unexplained differences between these sets of studies and the CBO results.
} 
change in redistribution fostered by the Social Security benefit formula between two cohorts, those who were 51 to 56 in 1992 and those 51 to 56 in $2004 .^{3}$

Of course, there are other changes affecting the value of benefits and taxes over that twelve year period. Social Security rules have been altered, raising the age at which an individual is entitled to full benefits, and thereby effectively reducing the value of Social Security benefits for members of younger cohorts. Moreover, an earnings test is no longer imposed after an individual reaches full retirement age. In addition, economic variables including interest rates, wages and productivity, have also changed over time. As interest rates decline, the value of benefits relative to taxes paid increases for members of cohorts nearing retirement age. Family structure has also changed, especially influenced by the increasing frequency of divorce.

It is difficult to standardize for all of these changes while maintaining a convincing underlying benefit structure. For example, one would not want to impose the benefit formula applicable to a 55 year old in 1992 on the real earnings of a 55 year old in 2004 . Under the formula applicable twelve years earlier, a person aged 55 with average earnings in 2004 would be treated as having earnings well above the mean for the earlier period. Although one could artificially grow earnings over the intervening period, it would greatly oversimplify matters to use some average measure of annual earnings growth since the earnings structure has changed over this period, not only changing occupational, educational and other differentials commonly examined in the labor economics literature, but also between men and women, and among those with different family types.

${ }^{3}$ This is the latest HRS cohort with matched Social Security earnings histories available at the time of writing this paper. The next youngest HRS cohort, the Mid Boomers, includes those ages 51 to 56 in 2010. Survey data became available in the summer of 2011. Matched Social Security earnings histories for the Mid Boomer cohort are not yet available at the time of writing. 
The simplest approach is to focus on the overall extent of redistribution relevant to each cohort, using actual earnings and interest rates for each year in question. Measures of redistribution will then be compared between cohorts both for individuals and families. Sensitivity of the findings to certain changes, for example the increase in frequency of households with a single, divorced person, will be examined. Thus we provide summary measures of the difference in redistribution under the Social Security benefit formula applying in each period, whatever the cause.

In the present paper, we concentrate on the change in redistribution of old age benefits experienced between the 1992 and 2004 cohorts from the Health and Retirement Study when individuals and households are arrayed by household covered earnings. For reasons of space, we do not duplicate all the steps taken in our earlier paper where we systematically examined the reasons for differences in distributions at the individual and family levels, including the correlation of earnings between husbands and wives by household income, and the relation of low earnings for women to years worked. In our earlier paper, we also emphasized that once the higher potential earnings of wives who chose not to spend much of their lifetime at work were taken into account, there was virtually no redistribution of benefits among households. Here we do not consider the earnings capacity of wives with limited commitment to the labor market over the life cycle. In both papers we focus only on redistribution of old age and survivors benefits and do not consider disability insurance. ${ }^{4}$

\footnotetext{
${ }^{4}$ In analyzing the redistribution of old age benefits fostered by the current system, we consider the payroll tax, but not the income taxation of Social Security. In a paper written at the same time as the present paper, Coe et al. (2011) do not find that income taxation of Social Security creates large changes in the measured progressivity of Social Security at the household level.
} 
Section II sets the stage for the analysis. It reviews how Social Security rules work, and the differences in labor market activities of cohorts of women in their early to mid-fifties in 1992 and 2004. Social Security measures are computed and compared between the two cohorts in Section III, focusing on the present values of Social Security benefits and taxes paid. Section IV then turns to the measures of distribution and redistribution fostered by the Social Security system, contrasting these measures between individuals and families within each cohort, and also between cohorts. In Section $\mathrm{V}$ we examine the robustness of the findings to changes in the frequency of divorced households and to differences in the interest rate. Section VI concludes.

\section{Framing the Problem}

The Social Security benefit formula determining an individual's own benefits from that person's own earnings history is designed to be progressive. For example, as we will explain in more detail below, for a person turning age 60 in 2004, on an annual basis the Primary Insurance Amount (PIA), the monthly benefit an individual is entitled to at normal retirement age based on own earnings, replaces 90 percent of the first $\$ 7,344$ of average indexed earnings, 32 percent of the next $\$ 36,924$, and 15 percent of remaining earnings up to the covered maximum.

These redistributive effects of the formula at the individual level are mitigated at the family level. When wives have lower earnings than their husbands, by averaging over the two spouses, a progressive benefit formula generates less redistribution between families than individuals. ${ }^{5}$ For men, there is a close correlation between their own lifetime earnings and the total of their own and their spouse's lifetime earnings. But for women the relationship is much

\footnotetext{
${ }^{5}$ When wives from high income families spend less time at work, they receive lower earnings not only because they accumulate fewer hours of paid work, but also because by working fewer hours or years, they are paid a lower wage rate than if they had been fully committed to the labor market.
} 
weaker (Gustman and Steinmeier, 2001, Table 1). Women from high income households are often low earners. Thus when comparing men and women with the same level of own lifetime earnings, family lifetime earnings are higher for women than for men. As a result, redistributing benefits toward households where the woman's earnings are low subsidizes many households where the sum of lifetime earnings for husbands and wives is quite high.

In addition, as long as spouse and survivor benefits accrue disproportionately to households with one high earner, the spouse and survivor benefits paid by Social Security undermine the redistribution of benefits away from high income families. Both spouse and survivor benefits are top-ups over own benefits. If the spouse has not accumulated ten years of covered earnings, and thus is not eligible for own benefits, the spouse or survivor benefit will account for the entire benefit check. When the lower earning spouse has accrued ten years of covered earnings, but those earnings amount to less than about one third the earnings of the higher earning spouse, the benefit check of the low earning spouse will be topped-up. The low earning spouse who receives benefits based both on own earnings and a top-up for spouse or survivor benefits is called a dual beneficiary. Only when both spouses have identical earnings histories are there no spouse or survivor benefits. ${ }^{6}$ Moreover, in a household with high earnings, the top-up is likely to have a higher value than in a household with low earnings (Steuerle and Bakija, 1994).

\footnotetext{
${ }^{6}$ We are ignoring here new claiming strategies for boosting the total value of Social Security benefits through manipulation of the claiming time of own and spouse benefits. For example, with two earners over the full retirement age, one person in the household may first claim benefits as a spouse, then claim own benefits at a higher annual rate because the initial claim date for own benefits has been postponed.
} 
To be sure, there is an increasing tendency over time for women from higher income families to participate more fully in the labor market. This led Smith, Toder and Iams (2003) and others to predict that even if the benefit formula remained unchanged, the current Social Security system would once again become more redistributive at the family level. ${ }^{7}$

Table 1 shows the differences in labor force participation, full-time work and lifetime covered earnings for a sample of individuals from the Health and Retirement Study. It includes two cohorts, those age 51 to 56 in 1992 (the HRS cohort) and those 51 to 56 in 2004 (the Early Boomer cohort). Over this period, women's labor market activity has increased substantially relative to men's (see also Iams et al., 2008). What was a 19 percentage point gap between the labor force participation rates of 51 to 56 year old men and women in 1992 declined to 8 percentage points in 2004. Similarly, what was a 25 percentage point gap between the fractions of 51 to 56 year old men and women working full time in 1992 declined to 16 percentage points in 2004. The third panel in Table 1 reports the annualized value of indexed monthly earnings covered by Social Security, here indicated as Average Indexed Monthly Earnings (AIME) times 12. ${ }^{8}$ The ratio of AIME between men and women declined from 2.85 in 1992 to 1.98 in 2004. Although the gaps in the measures of labor market activity between men and women are considerably smaller for the 2004 cohort than for the cohort twelve years older, they remain substantial.

\footnotetext{
${ }^{7}$ Note that Biggs, Sarney and Tamborini (2009) disagree with the predictions of Smith, Toder and Iams (2003). A part of the disagreement results from the different treatment of those who qualified for disability benefits at younger ages.

${ }^{8}$ AIME is computed from covered earnings and is increased by a wage index up to the year the individual turns age 60. Earnings are no longer indexed once the person reaches age 60 . The AIME is averaged using the highest 35 years of covered, indexed earnings. Earnings after age 60 will enter into the AIME calculation if they exceed indexed earnings in the lowest of the 35 years previously counted toward the AIME.
} 
Table 1: Labor Force Participation and Full-Time Work Patterns Over Time by Men and Women Ages 51 to 56 in 1992 and 2004

\begin{tabular}{|c|c|c|}
\hline & $\begin{array}{l}\text { HRS Cohort, } \\
51 \text { to } 56 \text { in } 1992\end{array}$ & $\begin{array}{l}\text { Early Boomers, } \\
51 \text { to } 56 \text { in } 2004\end{array}$ \\
\hline & \multicolumn{2}{|c|}{ Labor Force Participation } \\
\hline All Respondents & 73 & 75 \\
\hline Males & 83 & 79 \\
\hline \multirow[t]{2}{*}{ Females } & 64 & 71 \\
\hline & \multicolumn{2}{|c|}{ Percent Working Full Time } \\
\hline All Respondents & 64 & 66 \\
\hline Males & 77 & 74 \\
\hline \multirow[t]{2}{*}{ Females } & 52 & 58 \\
\hline & \multicolumn{2}{|c|}{$\mathrm{AIME} * 12$} \\
\hline All Respondents & 23,626 & 33,048 \\
\hline Males & 35,881 & 42,881 \\
\hline Females & 12,608 & 21,676 \\
\hline
\end{tabular}

Data are from the Health and Retirement Study. 


\section{Comparing Social Security Benefits and Taxes Between Cohorts}

Before generating the rates of return to Social Security benefits over taxes, it is useful to discuss in somewhat more detail how Social Security retirement benefits are determined at the individual and family levels. ${ }^{9}$ The Primary Insurance Amount (PIA) is the monthly Social Security benefit that would be received if claimed by the individual at full retirement age. It is calculated from Average Indexed Monthly Earnings (AIME). As noted above, for a person turning age 60 in 2004, on an annual basis the PIA replaces 90 percent of the first $\$ 7,344$ of annual earnings, 32 percent of the next $\$ 36,924$, and 15 percent remaining earnings through the covered maximum. Within the same household, the ratio of own benefits to own covered earnings will be greater for a lower earning spouse than for a higher earning spouse.

For members of the Early Boomer cohort, ages 51 to 56 in 2004 (born 1948 to 1953), full retirement age is 66 . The full retirement age has been increased by 2 months for each year born from 1955 through 1960 -- a fact that becomes relevant when we calculate benefits for households where one member falls within the 51 to 56 age range, and the other is younger. For those born in 1960 or later, the full retirement age is 67 . Similarly, the full retirement age may be lower than 66 for those with a spouse born before 1943 .

Spouse benefits are calculated as half of the benefits that the primary earner would receive at full retirement age. If the low earning spouse is entitled to own benefits that exceed half the benefits of the high earning spouse, there are no spouse benefits. Survivor benefits are calculated from the full benefit the primary earner would have been entitled to had he or she

\footnotetext{
${ }^{9}$ This study considers retirement benefits for each spouse. It does not include disability benefits, survivor benefits for young children or other such benefits provided by the Social Security system.
} 
survived. The formula for calculating full benefits may be adjusted to reduce the number of years of earnings counted if the deceased spouse died before reaching full retirement age. Survivor benefits are adjusted from the deceased spouse's Primary Insurance Amount, upward if the primary earner had delayed claiming benefits after reaching the full retirement age, or downward if the deceased spouse had claimed benefits early.

A person receiving spouse or survivor benefits is considered a dual beneficiary if that individual is also entitled to benefits based on own earnings that fall below the spouse or survivor benefit. Benefits based on own earnings are "topped up" to reach the benefit the individual is entitled to as a spouse or survivor. For example, if both spouses were the same age and retired at their full retirement age, with the high earning spouse entitled to a PIA of $\$ 900$, and the low earning spouse entitled to $\$ 100$ based on own earnings, the spouse benefit would top-up the benefit of the low earner from $\$ 100$ to $\$ 450$. If the higher earner died at full retirement age, the lower earning spouse would receive a total survivor benefit of $\$ 900$, including the top-up.

All benefits are adjusted based on the age they are claimed. Own benefits are adjusted downward when claimed early, and upward when benefit claiming is delayed beyond the full retirement age. Spouse and survivor benefits are also adjusted for early claiming by the primary earner and by the spouse.

For this paper, we use the Social Security Administration's ANYPIA program to calculate own benefits for members of the Health and Retirement Study. ${ }^{10}$ Because the ANYPIA program

${ }^{10}$ In some cases, ANYPIA makes different assumptions from those we made in our earlier paper (Gustman and Steinmeier, 2001). For example, in our earlier study, we rounded the 
does not calculate spouse and survivor benefits, we calculate spouse and survivor benefits from the own benefit calculations for each spouse. The ANYPIA program requires information on the date of birth of each spouse, covered earnings history, and the expected date at which benefits will be claimed. We provide the required information from the HRS survey and feed it into the ANYPIA program in batch mode. In the course of projecting benefits, ANYPIA uses the information from the HRS data to project earnings into the future, and to calculate the Primary Insurance Amount based on that information.

Table 2A reports the value of covered income and benefits of different types for individuals from the Early Boomer cohort of the Health and Retirement Study, those 51 to 56 in 2004. Social Security earnings records are available for about three fourths of the respondents to the HRS from Early Boomer households. Benefits and taxes are imputed for those in the cohort without a matched record. ${ }^{11}$

full retirement age to the nearest year, whereas ANYPIA keeps track of the full retirement age to the month.

${ }^{11}$ Imputations for those with a missing Social Security records are based on a nearest neighbor technique using a regression with the following covariates: if U.S. born, job tenure for longest job held, job tenure for current job, total number of years worked, number of jobs held, number of divorces, number of widowhoods, number of marriages, length of longest marriage, number of children, age, gender, education, race, union membership, earnings from current job, industry and occupation of current job, if self employed, if public employee, if retired, veteran, disabled, not in labor force, and employment status from 1992 to 2004. For households where one of the spouses was not interviewed we used an index indicating the respondent's gender, age, race, earnings, spouse's gender, age, race, earnings, and household assets.

There are two groups of donors for missing spouses of divorced respondents. For those who are not currently married, the donors are respondents, whether currently married or not, who are or had been divorced. In the case of donors who are divorced and not remarried, their marriage had to last at least 10 years. For missing spouses of widowed (widowered) respondents, the donors are respondents, whether currently married or not, who are or had been widowed (widowered). 
Column 1 reports the annual average for indexed earnings (AIME*12). Annual benefit amounts based on the individual's own work are reported in column 2 assuming retirement at the individual's expected retirement age. ${ }^{12}$ The present value of own benefits is reported in column 3. The remaining columns in Table 2A pertain to spouse and survivor benefits, attributing them in columns 4 and 5 to the person whose high earnings generated the top-ups for their spouse, and attributing the top-ups to the person who receives them in columns 7 and 8 . The rows in Table 2A first report results for all respondents, then separately for men by marital status, and then for women by marital status.

Looking across row 1 , annual indexed earnings average $\$ 33,048$ for each respondent, with the yearly value of AIME $\$ 42,881$ for men and \$21,676 for women. Roughly speaking, covered earnings for women are half those for men (the ratio of AIME of women to men is .505). Moreover, the gap is even wider within married households. Annualized AIME for married men is $\$ 46,433$, while for married women it is $\$ 21,615$, so that married women have 46.6 percent of the covered earnings of married men. The Primary Insurance Amount (PIA) multiplied by 12, $\$ 16,790$, is reported in column 2 .

Column 3 shows the present value of benefits based only on own work, with benefits beginning at the expected retirement age. Annual benefits are discounted to 2004 using interest rates from The Trustee's Report. ${ }^{13}$ Benefits are weighted by survival probabilities using a life

\footnotetext{
${ }^{12} \mathrm{We}$ also did the calculations in these tables assuming all individuals retired at their full retirement age. Those results are similar to the results reported in Table 2A and 2B. If the respondent reported an expected retirement age of less than 62 , the benefits are calculated using age 62 as the retirement age. If the respondent reported expected retirement at age 70 or later, or never expecting to retire, benefits are calculated assuming a retirement age of 70 .

${ }^{13}$ U.S. Social Security Administration (2010), Table VB.2. Additional Economic Factors, Page 104. The nominal rate is the average of the nominal interest rates for special U.S. Government
} 
table adjusted for variation in life expectancy with income and education. For individuals from households with at least one member age 51 to 56 in 2004, the present value of benefits based on own work is $\$ 135,358$. At $\$ 119,865$, the present value of benefits women will receive based on own earnings is 80.6 percent of the present value men will receive based on own earnings $(\$ 148,753)$. With women enjoying four fifths of the benefits from own earnings as men, women clearly benefit considerably from the redistributional benefit formula since, as noted above, women had about half the covered earnings of men.

For married men benefits are worth $\$ 157,770$. Benefits for divorced, widowered or never married men fall below those values. Divorced women living alone have benefits based on own work that are about 8.4 percent more valuable than the benefits earned by married women, and about one quarter more valuable than the benefits based on own earnings received by widows.

Columns 4, 5 and 6 credit the spouse who is the primary earner with any spouse and survivor benefits that will be paid as a result of the primary earner's covered income. Columns 4 and 5 report the values of the top-ups in benefits for qualifying spouses and for widowers or widows of primary earners, all adjusted by the probability the individual will fall into that state. ${ }^{14}$ Spouse and survivor benefits paid to the wives and widows of primary male earners, respectively, are seen in columns 4 and 5 , row 2 , to be worth $\$ 11,472$ and $\$ 45,066$, raising the total value of benefits earned by men from their work from $\$ 148,753$, the amount they would be

obligations issuable to the trust funds in each of the 12 months of the year. Historical values are used until 2010 and projections from the intermediate cost assumptions are used thereafter. ${ }^{14}$ Since we begin the calculation of survival probabilities at age 21, Table $2 \mathrm{~A}$ and subsequent tables include imputations for taxes paid by deceased spouses. Divorced spouses are also imputed. However, their benefits and taxes paid are not counted in the population totals since their spouse is presumably included in the divorced or married (for a second time) population of the other gender. Nevertheless, the benefits of the missing divorced spouse must be imputed to calculate the spouse or survivor benefits of the divorced person who is included in the sample. 
entitled to based on own earnings, to $\$ 205,291$, or by about 38 percent. ${ }^{15}$ Total benefits reported in column 6 , amounting to $\$ 167,636$, include own benefits plus any spouse or survivor benefits due to own earnings.

Comparing the values in columns 4 and 5, rows 2 and 7, it can be seen that the spouse and survivor benefits generated by women's earnings are only a small fraction of the spouse and survivor benefits due to the earnings of men. The basic reason is that, with most men having higher earnings than their wives, they are not entitled to any spouse or survivor benefits. On the other hand, wives with significant commitment to the labor market are entitled to a top-up as long as their covered earnings fall below those of their husbands. Moreover, with the significant degree of nonparticipation by wives shown in Table 1, adjustments for the timing of retirement aside, wives who are not eligible for own benefits are nevertheless eligible for half the benefits earned by their husband while both are still alive, and to their husband's full benefits should he die.

Columns 7, 8 and 9 report each individual's own earnings, plus spouse and survivor benefits paid to the individual based on their spouse's earnings. Here the spouse that receives the check from SSA is credited with spouse and survivor benefits even though their husband or wife accounted for the earnings and paid the taxes that underlie their benefits. In contrast to the results in columns 4 and 5, here men are credited with very little in the way of spouse and survivor benefits. Specifically, as seen in row 2, columns 7, 8 and 9, for men the top-up to own benefits from spouse benefits is $\$ 1,015$, while the expected value of survivor benefits is $\$ 2,672$.

\footnotetext{
${ }^{15}$ Ninety-two out of 1,344 married men have a positive spouse benefit. Average spouse benefit for this group is $\$ 16,522$. Out of 1,345 married women, 579 have a positive spouse benefit. Average spouse benefit for this group is $\$ 30,302$.
} 
Together, the spouse and survivor benefits received by men are worth only about 2.5 percent of the present value of the benefits they receive due to their own covered work.

Table 2B presents indicators of annual earnings and benefits for members of HRS households with at least one person aged 51 to 56 in 1992. To facilitate a comparison with Table 2A, the dollar amounts in Table 2B are reported in 2004 dollars.

At $\$ 23,626$, annual indexed covered earnings for the 1992 cohort are about 71 percent of the $\$ 33,048$ value reported for the 2004 cohort. A number of factors account for these differences. Among them are differences in real earnings and the lower cap on covered earnings for members of the 1992 cohort (Gustman, Steinmeier and Tabatabai, 2010). Another reason is the lower earnings of women in the earlier cohort. While earnings of women were about half the earnings of men in the 2004 cohort, AIME for the 1992 cohort is $\$ 35,881$ for men and $\$ 12,608$ for women, so that women from the 1992 cohort earned only about 35 percent of the covered earnings of men. ${ }^{16}$ Within married households, the gap in earnings between men and women was considerably wider for the 1992 cohort, with married women earning only 31 percent of the covered earnings of married men. This compares to 46.6 percent when comparing the earnings of married women and married men from the 2004 cohort.

${ }^{16}$ In 2004, 60.0 percent (weighted) of women living in a household with at least one person age 51 to 56 were married. In 1992, 70.4 percent of women were married. Most of the difference is accounted for by divorces. In 2004, 28.3 percent of women in this age range lived in a single person household and were divorced. The comparable number in 1992 is 16.4 percent. With fewer women in married households in 2004, the distribution of benefits across households is more unequal. This change in household structure is another reason for the observed differences between the two cohorts. We explore the sensitivity of the findings to the change in weight for divorced households below. 
Table 2A: Covered Earnings and Benefits Earned By Members of HRS Households in 2004 (in 2004 dollars)

\begin{tabular}{|c|c|c|c|c|c|c|c|c|c|c|}
\hline & \multicolumn{3}{|c|}{ Own Benefits } & \multicolumn{3}{|c|}{ Generated by Own Earnings } & \multicolumn{3}{|c|}{$\begin{array}{l}\text { Generated by Own \& Spouse's } \\
\text { Earnings }\end{array}$} & \multirow{2}{*}{$\begin{array}{l}\text { Number of } \\
\text { Obs. }\end{array}$} \\
\hline & $\begin{array}{l}\text { AIME } \\
* 12\end{array}$ & $\begin{array}{l}\text { Annual } \\
\text { Value of } \\
\text { PIA at Age } \\
\text { Respondent } \\
\text { Expects to } \\
\text { Claim SS } \\
\text { Benefits } \\
2\end{array}$ & $\begin{array}{l}\text { Present } \\
\text { Value of } \\
\text { Own } \\
\text { Benefits }\end{array}$ & $\begin{array}{l}\text { Spouse } \\
\text { Benefits } \\
\text { Average } \\
\text { Value of } \\
\text { Top-up for } \\
\text { Indicated } \\
\text { Population } \\
4\end{array}$ & $\begin{array}{l}\text { Survivor } \\
\text { Benefits } \\
\text { Average } \\
\text { Value of } \\
\text { Top-up for } \\
\text { Indicated } \\
\text { Population } \\
5\end{array}$ & $\begin{array}{l}\text { Total * } \\
\text { Benefits } \\
\text { Own }+ \\
\text { Spouse }+ \\
\text { Survivor } \\
\text { Benefits } \\
6\end{array}$ & $\begin{array}{l}\text { Spouse } \\
\text { Benefits } \\
\text { Average } \\
\text { Value of } \\
\text { Top-up for } \\
\text { Indicated } \\
\text { Population } \\
7\end{array}$ & $\begin{array}{l}\text { Survivor } \\
\text { Benefits } \\
\text { Average } \\
\text { Value of } \\
\text { Top-up for } \\
\text { Indicated } \\
\text { Population } \\
8\end{array}$ & $\begin{array}{l}\text { Total ** } \\
\text { Benefits } \\
\text { Own }+ \\
\text { Spouse + } \\
\text { Survivor } \\
\text { Benefits } \\
9\end{array}$ & \\
\hline \multicolumn{11}{|c|}{ VALUES FOR INDIVIDUAL RESPONDENTS } \\
\hline All Rs & 33,048 & 16,790 & 135,358 & 6,600 & 24,789 & 166,747 & 4,989 & 19,345 & 159,692 & 3764 \\
\hline All Males & 42,881 & 20,272 & 148,753 & 11,472 & 43,809 & 204,034 & 1,015 & 2,672 & 152,440 & 1791 \\
\hline Married Males & 46,433 & 21,334 & 157,770 & 13,921 & 53,210 & 224,901 & 1,074 & 2,971 & 161,815 & 1344 \\
\hline $\begin{array}{l}\text { Divorced Males } \\
\text { Living Alone }\end{array}$ & 37,378 & 19,061 & 134,159 & 6,832 & 25,881 & 166,872 & 1,353 & 2,860 & 138,372 & 244 \\
\hline Widowered Males & 22,927 & 14,089 & 110,586 & $\mathrm{NA}$ & NA & 110,586 & NA & NA & 110,586 & 113 \\
\hline $\begin{array}{l}\text { Never Married } \\
\text { Males }\end{array}$ & 25,065 & 13,912 & 97,273 & NA & NA & 97,273 & NA & NA & 97,273 & 90 \\
\hline All Females & 21,676 & 12,764 & 119,865 & 967 & 2,792 & 123,624 & 9,585 & 38,632 & 168,082 & 1973 \\
\hline Married Females & 21,615 & 12,509 & 117,384 & 1,353 & 3,472 & 122,209 & 12,342 & 48,661 & 178,387 & 1345 \\
\hline $\begin{array}{l}\text { Divorced Females } \\
\text { Living Alone }\end{array}$ & 22,768 & 13,477 & 127,262 & 451 & 2,437 & 130,150 & 7,211 & 32,000 & 166,473 & 406 \\
\hline Widowed Females & 16,202 & 10,857 & 101,569 & NA & NA & 101,569 & NA & NA & 101,569 & 124 \\
\hline $\begin{array}{l}\text { Never Married } \\
\text { Females } \\
\end{array}$ & 25,009 & 15,224 & 141,456 & NA & NA & 141,456 & NA & NA & 141,456 & 98 \\
\hline
\end{tabular}

Sample includes members of households where at least one individual is 51 to 56 in 2004 . All values use survey weights.

* Spouse and survivor benefits are attributed to individuals whose earnings generated the benefits. Total benefits (column 6$)=$ column $3+$ column $4+$ column 5 .

** Spouse and survivor benefits are generated based on individual's spouse's earnings. Total benefits (column 9) $=$ column $3+$ column $7+$ column 8. 
Table 2B: Covered Earnings and Benefits Earned By Members of HRS Households in 1992 (2004 dollars)

\begin{tabular}{|c|c|c|c|c|c|c|c|c|c|c|}
\hline & \multicolumn{3}{|c|}{ Own Benefits } & \multicolumn{3}{|c|}{ Generated by Own Earnings } & \multicolumn{3}{|c|}{ Generated by Spouse's Earnings } & \multirow{2}{*}{$\begin{array}{l}\text { Number of } \\
\text { Obs. }\end{array}$} \\
\hline & $\begin{array}{l}\text { AIME } \\
* 12\end{array}$ & $\begin{array}{l}\text { Annual } \\
\text { Value of } \\
\text { PIA at Age } \\
\text { Respondent } \\
\text { Expects to } \\
\text { Claim SS } \\
\text { Benefits } \\
2 \\
\end{array}$ & $\begin{array}{l}\text { Present } \\
\text { Value of } \\
\text { Own } \\
\text { Benefits }\end{array}$ & $\begin{array}{l}\text { Spouse } \\
\text { Benefits } \\
\text { Average } \\
\text { Value of } \\
\text { Top-up for } \\
\text { Indicated } \\
\text { Population } \\
4 \\
\end{array}$ & $\begin{array}{l}\text { Survivor } \\
\text { Benefits } \\
\text { Average } \\
\text { Value of } \\
\text { Top-up for } \\
\text { Indicated } \\
\text { Population } \\
5 \\
\end{array}$ & $\begin{array}{l}\text { Total * } \\
\text { Benefits } \\
\text { Own + } \\
\text { Spouse + } \\
\text { Survivor } \\
\text { Benefits }\end{array}$ & $\begin{array}{l}\text { Spouse } \\
\text { Benefits } \\
\text { Average } \\
\text { Value of } \\
\text { Top-up for } \\
\text { Indicated } \\
\text { Population } \\
7 \\
\end{array}$ & $\begin{array}{l}\text { Survivor } \\
\text { Benefits } \\
\text { Average } \\
\text { Value of } \\
\text { Top-up for } \\
\text { Indicated } \\
\text { Population } \\
8 \\
\end{array}$ & $\begin{array}{l}\text { Total ** } \\
\text { Benefits } \\
\text { Own + } \\
\text { Spouse + } \\
\text { Survivor } \\
\text { Benefits }\end{array}$ & \\
\hline \multicolumn{11}{|c|}{ VALUES FOR INDIVIDUAL RESPONDENTS } \\
\hline All Rs & 23,626 & 12,986 & 101,563 & 6,774 & 20,648 & 128,985 & 7,348 & 22,343 & 131,254 & 12,314 \\
\hline All Males & 35,881 & 18,210 & 132,066 & 15,201 & 46,148 & 193,415 & 442 & 907 & 133,414 & 5653 \\
\hline Married Males & 37,240 & 18,808 & 137,470 & 18,654 & 56,457 & 212,580 & 546 & 1,088 & 139,104 & 4769 \\
\hline $\begin{array}{l}\text { Divorced Males } \\
\text { Living Alone } \\
\end{array}$ & 32,291 & 16,505 & 115,433 & 1,490 & 5,581 & 122,505 & 13 & 171 & 115,617 & 596 \\
\hline Widowered Males & 29,134 & 15,445 & 109,706 & NA & NA & 109,706 & NA & NA & 109,706 & 92 \\
\hline $\begin{array}{l}\text { Never Married } \\
\text { Males }\end{array}$ & 24,664 & 13,565 & 92,772 & NA & NA & 92,772 & NA & NA & 92,772 & 196 \\
\hline All Females & 12,608 & 8,288 & 74,135 & 286 & 938 & 75,359 & 12,468 & 38,398 & 125,001 & 6661 \\
\hline Married Females & 11,586 & 7,686 & 68,821 & 404 & 1,284 & 70,510 & 17,589 & 54,135 & 140,546 & 4889 \\
\hline $\begin{array}{l}\text { Divorced Females } \\
\text { Living Alone }\end{array}$ & 15,032 & 10,152 & 90,169 & 4 & 206 & 90,379 & 260 & 1,208 & 91,637 & 977 \\
\hline Widowed Females & 12,060 & 8,143 & 72,769 & NA & NA & 72,769 & NA & NA & 72,769 & 565 \\
\hline $\begin{array}{l}\text { Never Married } \\
\text { Females }\end{array}$ & 23,739 & 12,223 & 111,058 & NA & NA & 111,058 & NA & NA & 111,058 & 230 \\
\hline
\end{tabular}

Sample includes members of households where at least one individual is 51 to 56 in 1992. All values are reported in 2004 dollars and are calculated using survey weights.

* Spouse and survivor benefits attributed to individuals whose earnings generated the benefits. Total benefits (column 6) = column $3+$ column $4+$ column 5 .

** Spouse and survivor benefits are generated based on individual's spouse's earnings. Total benefits $($ column 9$)=$ column $3+$ column $7+$ column 8 . 
For the 2004 cohort, we noted that based on own earnings, the present value of benefits received by women amounts to about four fifths of the present value of benefits men receive based on own earnings. For the 1992 cohort, the relevant amounts for women and men, again in 2004 dollars, were $\$ 74,135$ and $\$ 132,066$. Thus the 1992 cohort of women enjoyed only 56 percent of the benefits from own earnings as men. Again, the major growth in women's earnings is plainly evident in the data, even between cohorts separated by only 12 years of age.

In addition, for the 2004 cohort, we found that spouse and survivor benefits paid to the wives and widows of primary male earners increased the total value of benefits earned by men from the amount they would be entitled to based on own earnings by about 37 percent $(11,472+43,809) / 148,753$. For the 1992 cohort, spouse and survivor benefits were more important, raising the total value of benefits by 46.5 percent $(15,201+46,148) / 132,066$.

It is also constructive to compare the relative importance of spouse and survivor benefits to own benefits for women. From Table 2B, using data for the 1992 cohort, columns 7, 8 and 9, row 7 , spouse and survivor benefits accounted for 68.6 percent of the total benefits women would receive from own earnings $(12,468+38,398) / 74,135$. For the 2004 cohort, spouse and survivor benefits accounted for 40.2 percent of the total benefits eventually to be received by women $(9,585+38,632) / 119,865$.

In contrast to the results for individuals reported in Tables 2A and 2B, Table 3 reports benefit values for households with at least one member age 51 to 56 . The two rows compare outcomes between the 2004 and 1992 cohorts evaluated in 2004 dollars. Household benefits count the total of benefits received, from own earnings and from spouse and survivor benefits. 
Table 3: Covered Earnings and Benefits for Members of HRS Households with at Least One Individual Age 51 to 56 in 2004 and 1992

\begin{tabular}{|c|c|c|c|c|c|c|c|}
\hline & \multicolumn{3}{|c|}{ Own Benefits } & \multirow{2}{*}{$\begin{array}{l}\text { Spouse } \\
\text { Benefits } \\
\text { Average } \\
\text { Value of } \\
\text { Top-up for } \\
\text { Indicated } \\
\text { Population }\end{array}$} & \multirow{2}{*}{$\begin{array}{l}\text { Survivor } \\
\text { Benefits } \\
\text { Average } \\
\text { Value of } \\
\text { Top-up for } \\
\text { Indicated } \\
\text { Population }\end{array}$} & \multirow{2}{*}{$\begin{array}{l}\text { Total } \\
\text { Benefits }\end{array}$} & \multirow{2}{*}{$\begin{array}{l}\text { Share of Total } \\
\text { Benefits Due to } \\
\text { Spouse and } \\
\text { Survivor } \\
\text { Benefits }\end{array}$} \\
\hline & $\begin{array}{l}\text { AIME } \\
* 12\end{array}$ & $\begin{array}{l}\text { PIA at Age } \\
\text { Respondent } \\
\text { Expects to } \\
\text { Claim SS } \\
\text { Benefits }\end{array}$ & $\begin{array}{l}\text { Present Value } \\
\text { of Own } \\
\text { Benefits }\end{array}$ & & & & \\
\hline $\begin{array}{l}\text { All Households } \\
2004\end{array}$ & 56,396 & 30,073 & 220,040 & 10,473 & 40,526 & 271,093 & 0.188 \\
\hline $\begin{array}{l}\text { All Households } \\
1992 \text { in } 2004 \text { dollars }\end{array}$ & 37,498 & 20,776 & 160,756 & 11,560 & 36,574 & 208,890 & 0.230 \\
\hline
\end{tabular}

The number of households in the 2004 sample is 2,287. In the 1992 sample there are 7,611 households. Values are calculated using survey weights. 
As seen in the next to last column of row 1, in 2004 the present value of total benefits in each household averaged $\$ 271,093$. Benefits from own earnings amounted to $\$ 220,040$, with a top-up for spouse benefits of $\$ 10,473$, and for survivor benefits of $\$ 40,526$. Thus benefits from own earnings account for over four fifths of total benefits (81.2 percent), while as shown in the last column of the table, the top-up for spouse and survivor benefits accounts for a little under one fifth (18.8 percent) of total benefits.

Row 2 reports comparable figures for those ages 51 to 56 in 1992. To facilitate comparisons, present values are calculated in constant 2004 dollars. In 1992, 23.0 percent of total benefits were in the form of spouse and survivor benefits $(\$ 11,560+\$ 36,574) / \$ 208,890$. Thus with the increase in women's labor force participation and earnings, the share of total benefits enjoyed by households from spouse and survivor benefits fell from 23.0 percent in 1992 to 18.8 percent of total benefits between 1992 and 2004.

Table 4 provides a picture of the trends in benefits and taxes at the individual and family levels. ${ }^{17}$ As seen in rows 1 and 2 of column 2, for members of the 1992 HRS cohort, the present values of benefits and taxes based on own earnings were roughly equal at $\$ 106,000$ and $\$ 102,000$ respectively. By 2004 , benefits based on own work amounted to only 81 percent of taxes paid. This decline in the returns to Social Security taxes reflects the changes in the benefit structure implemented to help solve the financial problems of the Social Security system, and shows itself in one form or another in all comparisons between the two cohorts.

\footnotetext{
${ }^{17}$ In calculating the tax rate, we include both the employer's and the worker's share of the tax. Because this study focuses only on retirement benefits, the payroll tax rate we use does not include the taxes that support disability benefits or Medicare benefits. For example, the relevant payroll tax rate used in our calculations for the years after 2000 is 10.6 percent.
} 
It is instructive to consider the changes for men and women separately. Real taxes increased by 37 percent for men, but reflecting the major changes in their lifetime participation and resulting earnings, taxes increased by 86 percent for women. Own benefits increased by only 12.6 percent for men $(132,066 / 148,753)$. On the other hand, for women, own benefits grew by 61.7 percent, reflecting the overwhelming trend in their participation and resulting positive effects on earnings.

As found in the data for own benefits and taxes, benefits grew more slowly than taxes at the household level. The last column in the bottom panel of Table 4 shows that household Social Security benefits rose by 30 percent between the 2004 and 1992 cohorts, while taxes paid at the household level rose by 53 percent. (This result is partially affected by the change in the composition of households between 1992 and 2004, an issue we will return to below.) In 2004 at the household level, the present value of Social Security benefits, at $\$ 271,000$, slightly exceeded the present value of taxes paid, at $\$ 260,000$, by four percent. In contrast, as seen in the last row in column 2, in 1992, the initial year of the HRS, total benefits at the household level exceeded taxes by about 23 percent. As a result of the slower relative growth of benefits, by 2004 the benefit-tax ratio had fallen by 19 percent from its level in 1992. 
Table 4: Present Values of Social Security Benefits and Taxes for Individuals and Households, from Households with at Least One Person Age 51 to 56 in 2004 or 1992. (All Values in Thousands of 2004 Dollars)

\begin{tabular}{|c|c|c|c|}
\hline & 2004 Cohort & 1992 Cohort & $\begin{array}{c}\text { Ratio } 2004 \text { Cohort to } 1992 \\
\text { Cohort }\end{array}$ \\
\hline \multicolumn{4}{|c|}{ Own Benefits and Taxes } \\
\hline \multicolumn{4}{|c|}{ (1) } \\
\hline Average lifetime taxes & 166 & 106 & 1.57 \\
\hline $\begin{array}{l}\text { Average lifetime } \\
\text { benefits }\end{array}$ & 135 & 102 & 1.32 \\
\hline Benefits/Taxes & .81 & .96 & .84 \\
\hline \multicolumn{4}{|l|}{ Men } \\
\hline Average lifetime taxes & 215 & 157 & 1.37 \\
\hline $\begin{array}{l}\text { Average lifetime } \\
\text { benefits }\end{array}$ & 149 & 132 & 1.13 \\
\hline Benefits/Taxes & .69 & .84 & .82 \\
\hline \multicolumn{4}{|l|}{ Women } \\
\hline Average lifetime taxes & 110 & 59 & 1.86 \\
\hline $\begin{array}{l}\text { Average lifetime } \\
\text { benefits }\end{array}$ & 120 & 74 & 1.62 \\
\hline Benefits/Taxes & 1.09 & 1.25 & .87 \\
\hline \multicolumn{4}{|c|}{ Household Benefits and Taxes } \\
\hline Average lifetime taxes & 260 & 170 & 1.53 \\
\hline $\begin{array}{l}\text { Average lifetime } \\
\text { benefits }\end{array}$ & 271 & 209 & 1.30 \\
\hline Benefits/Taxes & 1.04 & 1.23 & .85 \\
\hline
\end{tabular}

Values are calculated using survey weights. 


\section{Comparing Measures of Distribution and Redistribution Between Cohorts}

\section{A. Distribution and Redistribution of Own Benefits and Taxes}

Table 5 reports a variety of measures of benefit and tax distribution and redistribution for the individuals in the Early Boomer Cohort in 2004, members of households with at least one person age 51 to 56 in 2004 . The population is divided into deciles according to their annualized Average Indexed Monthly Earnings and outcomes are reported separately by AIME decile. The first two rows report the present values of taxes and benefits as of 2004. Values are weighted by survival probability, which includes adjustments for income. The present values of taxes and benefits for the full sample of Early Boomers is reported in the last column of the table.

The first set of measures of redistribution involves a simple comparison of benefits and taxes for members of each AIME decile. Row 3 reports the ratio of the present value of benefits to taxes paid over the expected lifetime. In this comparison, benefits include only those due to own earnings. Although there are positive benefits shown for members falling within the decile with the lowest ten percent of covered earnings, there is no redistribution to individuals falling in that decile in the sense that their benefits fall below taxes paid. Many falling into the bottom AIME decile have not worked for the required ten years and thus do not qualify for Social Security benefits. Benefits do exceed taxes for those falling in the second to fifth AIME deciles, then fall below taxes for those in the remaining deciles. For those in the second, third and fourth deciles, there is significant redistribution. Own benefits exceed own taxes by 53 percent, 59 percent and 23 percent respectively. The ratio of the present value of benefits to taxes for the full cohort is $.81(135 / 166)$ as reported in the last column of row 3.

Row 4 of Table 5 reports a second measure of the extent of redistribution fostered by the benefit formula. The baseline is taken as the level of benefits that would be received by members of the decile 
based on own earnings if their benefits amounted to 81 percent of the taxes they paid, the average ratio for the Early Boomer Cohort. That is, the baseline asks what benefits would be if the benefit-tax ratio for members of the decile were the same as the benefit-tax ratio for all members of the Early Boomer cohort. For example, from column 3, row 4 of the table, members of the third AIME decile receive benefits that are 84 percent higher than they would be if their benefits amounted to 81 percent of the taxes they paid. Moving across the columns in row 4, those in the second to seventh deciles of AIME receive benefits that exceed what they would have received at 81 percent of the taxes they paid. Those in the last three deciles have had their benefits reduced by the progressive benefit formula. Members of the decile with highest AIME have their benefits reduced by 32 percent below what they would have been with an 81 percent replacement rate.

Another measure of redistribution asks about the share of total benefits paid to members of the cohort that is redistributed to the members of each decile. Specifically, the figures in row 5 divide the benefits redistributed to the decile by the total value of benefits paid to members of the Early Boomer cohort. Altogether, 11.39 percent of total benefits paid (-1.51 -3.50 -6.38) are redistributed from members of the three highest AIME deciles to the remainder of the population. Those falling in the lowest decile also receive benefits that fall slightly below the taxes they paid, with the shortfall amounting to 0.3 percent of total benefits paid to members of the cohort. 
Table 5: Baseline Measures of Distribution and Redistribution of Own Social Security Benefits and Taxes for All Age Eligible Respondents in the Early Boomer Cohort in 2004

\begin{tabular}{|c|c|c|c|c|c|c|c|c|c|c|c|}
\hline & \multicolumn{11}{|c|}{ Annualized individual AIME deciles: 2004 (2004 dollars) } \\
\hline & $0-4 \mathrm{~K}$ & $4-9$ & $9-14$ & $14-20$ & $20-27$ & $27-35$ & $35-44$ & $44-57$ & $57-73$ & $73+$ & All \\
\hline Average lifetime taxes & $\$ 10 \mathrm{~K}$ & 34 & 59 & 91 & 124 & 163 & 204 & 258 & 324 & 399 & 166 \\
\hline Average lifetime benefits & 7 & 52 & 94 & 112 & 131 & 149 & 177 & 196 & 212 & 225 & 135 \\
\hline Average lifetime benefits/taxes & 0.7 & 1.5 & 1.6 & 1.2 & 1.1 & 0.9 & 0.9 & 0.8 & 0.7 & 0.6 & .81 \\
\hline $\begin{array}{l}\text { Measure of redistribution } \% \text { by which } \\
\text { benefits are increased }\end{array}$ & $-34 \%$ & 77 & 84 & 46 & 22 & 10 & 0.8 & -9 & -20 & -32 & - \\
\hline $\begin{array}{l}\text { Share of total benefits redistributed to } \\
\text { the decile }\end{array}$ & $-0.30 \%$ & 2.06 & 3.42 & 3.01 & 1.96 & 1.13 & 0.11 & -1.51 & -3.50 & -6.38 & 11.68 \\
\hline \multicolumn{12}{|l|}{ Rate of return percentiles* } \\
\hline $90 \%$ & 1.5 & 5.3 & 5.0 & 4.4 & 4.2 & 3.6 & 3.3 & 2.7 & 2.2 & 1.5 & 4.5 \\
\hline $75 \%$ & & 5.0 & 4.6 & 3.8 & 3.5 & 3.0 & 2.6 & 2.3 & 1.6 & 0.8 & 3.2 \\
\hline $50 \%$ & & 4.4 & 4.2 & 3.1 & 2.8 & 2.4 & 2.0 & 1.5 & 0.8 & 0.1 & 1.8 \\
\hline $25 \%$ & & 2.8 & 3.1 & 2.2 & 1.9 & 1.5 & 1.3 & 0.7 & 0.1 & -0.6 & 0.1 \\
\hline $10 \%$ & & & 2.2 & 1.3 & 1.2 & 0.8 & 0.4 & .04 & -0.5 & -0.9 & - \\
\hline
\end{tabular}

* The base year for the rate of return calculation for the Early Boomer cohort is 2004. 
The bottom panel of Table 5 reports real rates of return by AIME decile computed conditional on survival. Looking at the last column, row 3 of the bottom panel, the median value for the real rate of return is 1.8 percentage points. It would appear both from the declining amount of redistribution as AIME increases across rows 3 and 4 of the top panel of Table $3 \mathrm{~A}$, and from the rapid decline in rate of return with AIME, that there is considerable redistribution fostered by the progressive benefit formula when evaluated considering own benefits and taxes at the level of the individual.

Table 6 reports comparable results based on the distribution of own taxes and benefits for members of the original HRS cohort, those ages 51 to 56 in 1992. Beginning with rows 1 through 3 , the simple comparison of benefits and taxes for members of each AIME decile suggests considerable redistribution. Benefits substantially exceed taxes for those falling in the third to sixth AIME deciles. A comparison with results in Table 5 suggests that redistribution extends to members with higher relative incomes in 1992 than in 2004. For the 2004 cohort, those in the second, third and fourth deciles had own benefits exceed own taxes by 53 percent, 59 percent and 23 percent respectively. For the 1992 cohort, benefits exceeded taxes by 71 percent (48/28), 65 percent (79/48), 32 percent (98/74) and 15 percent (117/102) for members of the third, fourth, fifth and sixth AIME deciles respectively. While these raw numbers suggest there may have been more redistribution in 1992 than in 2004, the benefit reduction for members of the top three AIME categories suggests otherwise. Looking at the last column of row 5 in Tables 5 and 6, in 2004, 11.68 percent of total benefits paid to the cohort was redistributed from members of the three highest earning deciles. This is a greater amount of redistribution than in 1992, when 9.53 percent of total benefits paid was redistributed from members of the top AIME deciles. 
Table 6: Baseline Measures of Distribution and Redistribution of Own Social Security Benefits and Taxes for All Age Eligible Respondents in the HRS, 1992

\begin{tabular}{|c|c|c|c|c|c|c|c|c|c|c|c|}
\hline & \multicolumn{11}{|c|}{ Annualized individual AIME deciles: 1992 (2004 dollars) } \\
\hline & $0-1 \mathrm{~K}$ & $1-4$ & $4-8$ & $8-13$ & $13-19$ & $19-27$ & $27-35$ & $35-44$ & $44-52$ & $52+$ & All \\
\hline Average lifetime taxes & 2 & 13 & 28 & 48 & 74 & 102 & 138 & 175 & 217 & 257 & 104 \\
\hline Average lifetime benefits & 0 & 11 & 48 & 79 & 98 & 117 & 139 & 151 & 176 & 196 & 102 \\
\hline Average lifetime benefits/taxes & 0 & 0.8 & 1.7 & 1.6 & 1.3 & 1.1 & 1.0 & 0.8 & 0.8 & 0.8 & 0.98 \\
\hline $\begin{array}{l}\text { Measure of redistribution \% by which benefits } \\
\text { are increased }\end{array}$ & -98 & -19 & 68 & 64 & 34 & 15 & 0.4 & -11 & -16 & -20 & - \\
\hline $\begin{array}{l}\text { Share of total benefits redistributed to the } \\
\text { decile }\end{array}$ & -0.30 & -0.26 & 1.92 & 3.24 & 2.65 & 1.65 & 0.07 & -2.00 & -3.02 & -3.95 & 9.53 \\
\hline \multicolumn{12}{|l|}{ Rate of return percentiles* } \\
\hline $90 \%$ & - & 6.4 & 6.8 & 6.2 & 5.3 & 4.8 & 4.4 & 3.9 & 3.4 & 2.6 & 5.5 \\
\hline $75 \%$ & - & 4.8 & 6.2 & 5.7 & 4.8 & 4.4 & 3.9 & 3.4 & 2.8 & 2.0 & 4.2 \\
\hline $50 \%$ & & - & 5.3 & 4.9 & 3.9 & 3.6 & 3.1 & 2.7 & 2.1 & 1.1 & 2.6 \\
\hline $25 \%$ & & & 2.5 & 3.4 & 2.7 & 2.3 & 2.1 & 1.8 & 1.3 & 0.30 & 0.5 \\
\hline $10 \%$ & & & & 2.0 & 1.6 & 1.4 & 1.1 & 0.9 & 0.6 & 0.5 & - \\
\hline
\end{tabular}

* The base year for the rate of return calculation for the HRS cohort is 1992. 
Comparing rates of return between the two cohorts, the real median rate of return fell from 2.6 percent in 1992 to 1.8 percent in 2004. Again, roughly speaking, the rate of return to those in the top three deciles in 2004 is lower than in 1992. Although this might be taken to suggest there is more redistribution in 2004 than in 1992, it should be remembered that the overall rate of return is lower in 2004.

To be sure, the data in rows 3 and 4 of the top panel of Tables 5 and 6 do generate a bottom line regarding the various measures of distribution and redistribution at the level of the individual. The amount of redistribution of own benefits was somewhat, but not overwhelmingly higher for the 2004 cohort than for the 1992 cohort.

\section{B. Differences in Redistribution Among Households by Cohort}

Table 7 turns to data on benefits and taxes for households, counting within benefits paid not only benefits based on own work, but also including spouse and survivor benefits. Once households are considered, the picture changes. Recall our finding in Table 5 that in 2004, 11.7 percent of benefits was redistributed from individuals falling within the three top deciles of earners to those in lower deciles. In the top panel of Table 7, which pertains to households in 2004, we find that 7.08 percent (-.42 - 2.17 .48) of benefits are redistributed from members of the top three deciles of household units. Remember here that there are at least two major differences between redistribution among individuals and households. First, although individual and household earnings are imperfectly but positively related for men, the relationship is much weaker for women. Second, the data in Table 7 include the top-ups on own benefits for spouse and survivor benefits.

When these factors are taken into account, although there is redistribution, it is considerably less at the level of the household than at the level of the individual. This bottom line from our earlier work 
and those of other authors remains. Although the benefit formula is designed to be redistributive, and is redistributive at the level of the individual, lower earnings of women and the presence of spouse and survivor benefits at the household level continue to reduce the degree of redistribution fostered by the Social Security benefit formula.

On the other hand, there are important changes indicating that the redistribution fostered by the Social Security benefit formula has increased over time. The differences between the top and bottom panels of Table 7 show the extent of redistribution at the household level for the cohort of $2004 .{ }^{18}$ The amount of redistribution at the household level is higher in 2004 than in 1992. Moreover, the increase in redistribution through 2004 is greater at the household level than at the level of the individual.

\footnotetext{
${ }^{18}$ In our earlier study we found five percent of the total benefits accruing to households are redistributed from households falling in the top three deciles of earners. The results from our earlier study, which pertained to the full, original HRS cohort in 1992, are not comparable to the findings for the Early Boomer cohort. There are a number of sources of difference. For one thing, the 1992 cohort examined in our earlier paper is older (51 to 61 years old) in the base year than are the samples of 51 to 56 year olds. This means that for the original HRS cohort, benefits were discounted over fewer years than they are for the cohorts examined in this paper. That is, it takes fewer years between the date of the survey and the date Social Security benefits are first collected for a cohort that is 51 to 61 years old than for a cohort that is 51 to 56 years old. Age differences aside, other factors create differences between the Early Boomer and Original HRS cohorts. As mentioned previously, the age of receipt of full benefits was lower for the HRS cohort, who did not face the complete increase of the full retirement age to 66. In addition, interest rates were much higher during their period of high earnings for the HRS cohort. As a result, the value of their tax contributions is increased. One might consider a simulation exercise where those aged 51 to 56 in 1992 are given a birth date that occurs twelve years later. However, the members of the Original HRS cohort would have lower earnings than the Early Boomers. Adjusting for growth in earnings would require also adjusting for changes in the occupational and educational distribution of earnings, a task well outside the scope of this paper.
} 
Table 7: Measures of Distribution of Household Social Security Benefits and Taxes for All Age Eligible Respondents, Early Boomer and Original HRS Cohorts

\begin{tabular}{|c|c|c|c|c|c|c|c|c|c|c|c|}
\hline & \multicolumn{11}{|c|}{ Annualized Household AIME deciles: 2004 (2004 dollars) } \\
\hline & $0-12 \mathrm{~K}$ & $12-23$ & $23-33$ & $33-41$ & $41-52$ & $52-63$ & $63-75$ & $75-88$ & $88-103$ & $103+$ & All \\
\hline Average family lifetime taxes & $\$ 32 \mathrm{~K}$ & 87 & 138 & 180 & 218 & 279 & 316 & 365 & 435 & 547 & 260 \\
\hline Average family lifetime benefits* & 55 & 136 & 186 & 214 & 258 & 308 & 337 & 374 & 401 & 440 & 271 \\
\hline Average family lifetime benefits/taxes & 1.7 & 1.6 & 1.3 & 1.2 & 1.2 & 1.1 & 1.1 & 1.0 & 0.9 & 0.8 & 1.04 \\
\hline $\begin{array}{l}\text { Measure of redistribution } \% \text { by which } \\
\text { benefits are increased }\end{array}$ & $60 \%$ & 49 & 28 & 15 & 10 & 4 & -0.01 & -3 & -14 & -23 & - \\
\hline \multirow[t]{3}{*}{$\begin{array}{l}\text { Share of total benefits redistributed to } \\
\text { decile }\end{array}$} & $1.00 \%$ & 1.93 & 1.76 & 1.08 & 0.89 & 0.44 & -0.00 & -0.42 & -2.17 & -4.48 & 7.08 \\
\hline & \multicolumn{11}{|c|}{ Annualized Household AIME deciles: 1992 (2004 dollars) } \\
\hline & $0-5 \mathrm{~K}$ & $5-13$ & $13-21$ & $21-29$ & $29-37$ & $37-44$ & $44-51$ & $51-59$ & $59-69$ & $69+$ & All \\
\hline Average family lifetime taxes & $\$ 10 \mathrm{~K}$ & 39 & 76 & 113 & 149 & 185 & 220 & 249 & 287 & 365 & 170 \\
\hline Average family lifetime benefits & 8 & 70 & 115 & 158 & 204 & 239 & 273 & 300 & 342 & 379 & 209 \\
\hline Average family lifetime benefits/taxes & 0.8 & 1.8 & 1.5 & 1.4 & 1.4 & 1.3 & 1.2 & 1.2 & 1.2 & 1.0 & 1.23 \\
\hline $\begin{array}{l}\text { Measure of redistribution \% by which } \\
\text { benefits are increased }\end{array}$ & $-33 \%$ & 45 & 23 & 12 & 9 & 3 & 1.1 & -2.1 & -3.8 & -16.1 & - \\
\hline $\begin{array}{l}\text { Share of total benefits redistributed to } \\
\text { decile }\end{array}$ & $-0.22 \%$ & 1.13 & 1.14 & 0.84 & 0.86 & 0.37 & 0.14 & -0.30 & -0.63 & -3.36 & 4.51 \\
\hline
\end{tabular}

* Household benefits include own benefit plus top-ups for spouse and survivor benefits. 
These findings are summarized in Figure 1. While the share of total benefits redistributed at the individual level increased from 9.51 percent in 1992 to 11.68 percent in 2004, the share of total benefits redistributed among households increased from 4.51 percent in 1992 to 7.08 percent in 2004 . Thus the gap between the shares of benefits redistributed among individuals vs. at the household level remains roughly the same for these two cohorts. That is, redistribution based on own benefits for the 1992 cohort (9.53) minus redistribution based on family benefits (4.51) shows a difference in the level of redistribution between the individual and household levels of 5.02 percentage points. The comparable figure for the 2004 cohort is 4.60 percentage points $(11.68-7.08)$. Redistribution at the household level remains smaller than the measured redistribution among individuals.

Figure 2 compares the rates of return by AIME decile at the family level. The data underlying Figure 2 are reported in Tables $8 \mathrm{~A}$ and $8 \mathrm{~B}$. Looking at the third row, the rate of return for members of the second AIME decile (column 2) had a median value of 3.3 percentage points in 2004 and 5.1 percentage points in 1992. By the highest decile of earners, the median value has fallen to 0.5 percentage points in 2004 from 1.5 percentage points in 1992.

Contrary to the direct measures of benefit redistribution reported above, as seen in Figure 2, although the rates of return are lower in 2004 than in 1992, they decline at roughly the same rate for each cohort when proceeding from low to high AIME deciles. Thus a comparison of the distributions of rates of returns by AIME decile does not suggest a strong difference in benefit redistribution for members of the 2004 cohort. 
Figure 1

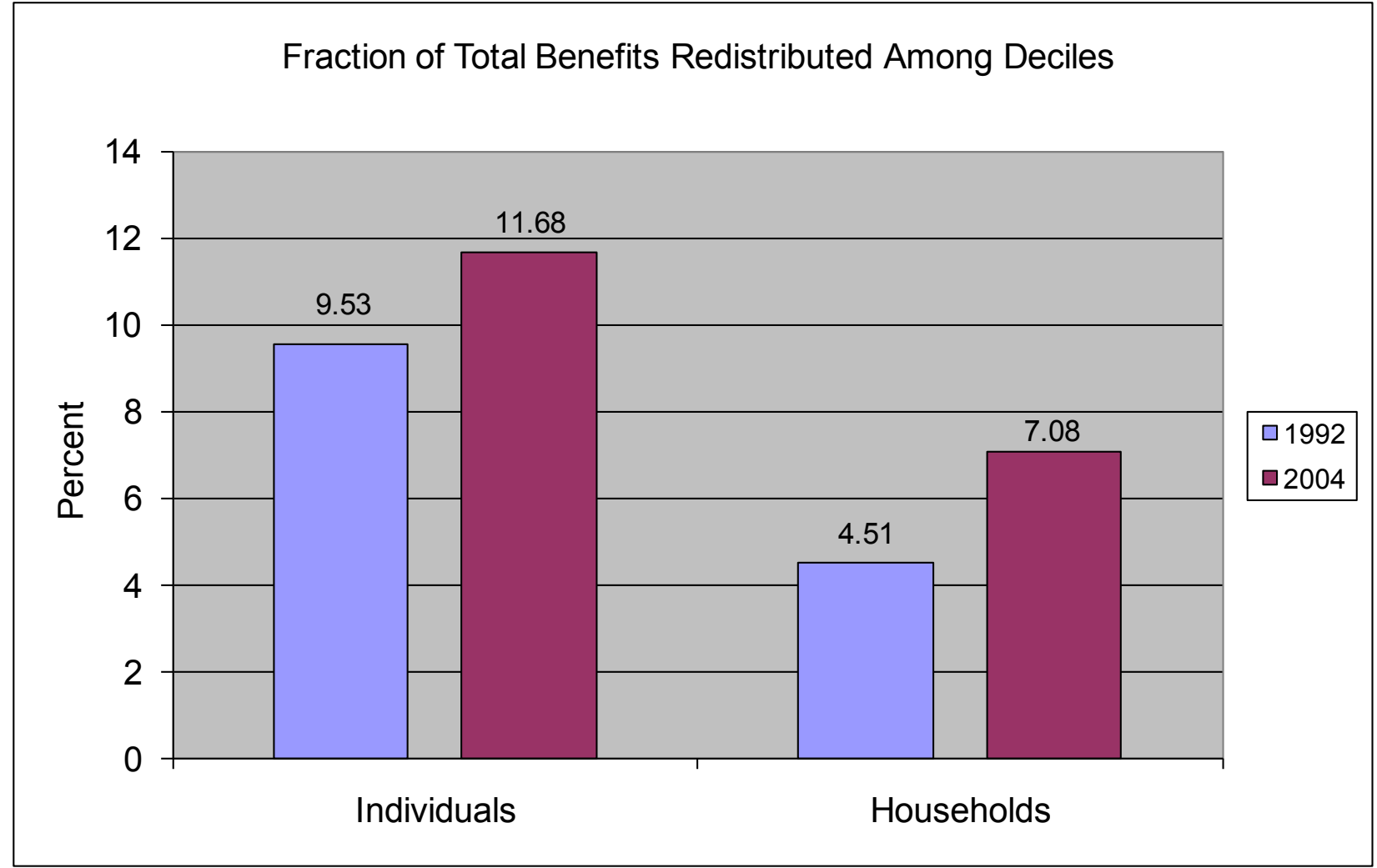

Figure 2

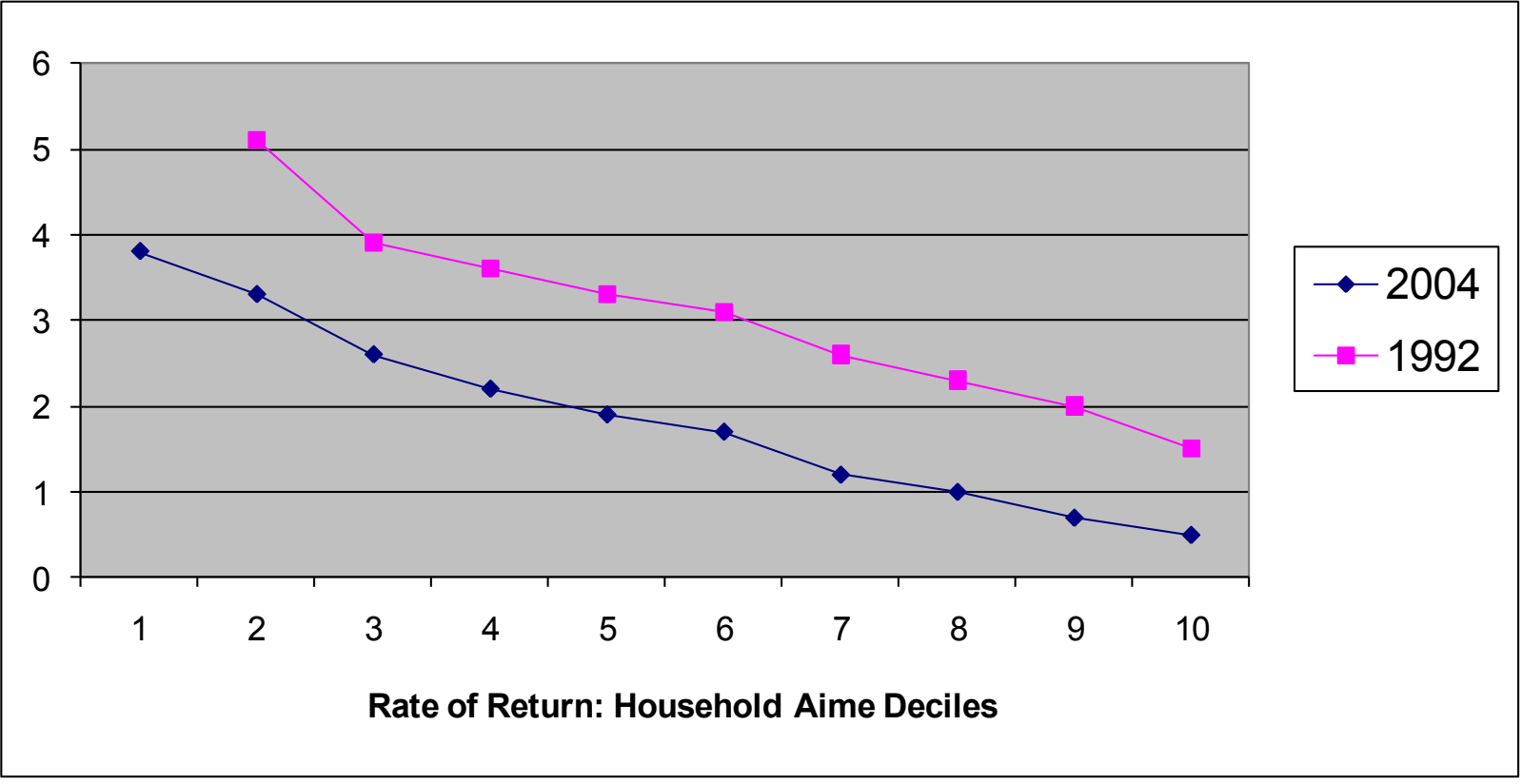


Table 8A: Rates of Return on Social Security Benefits and Taxes by AIME Decile, Early Boomer Cohort, Ages 51 to 56 in 2004

\begin{tabular}{|c|c|c|c|c|c|c|c|c|c|c|c|}
\hline & \multicolumn{11}{|c|}{ Annualized Household AIME deciles: 2004 (2004 dollars) } \\
\hline & $0-12 \mathrm{~K}$ & $12-23$ & $23-33$ & $33-41$ & $41-52$ & $52-63$ & $63-75$ & $75-88$ & $88-103$ & $103+$ & All \\
\hline \multicolumn{12}{|c|}{ Rate of return percentiles 2004} \\
\hline $90 \%$ & 5.1 & 4.4 & 4.1 & 3.6 & 3.3 & 3.0 & 2.6 & 2.2 & 2.1 & 1.8 & 3.8 \\
\hline $75 \%$ & 4.7 & 3.9 & 3.3 & 2.9 & 2.6 & 2.5 & 2.0 & 1.8 & 1.6 & 1.2 & 2.7 \\
\hline $50 \%$ & 3.8 & 3.3 & 2.6 & 2.2 & 1.9 & 1.7 & 1.2 & 1.0 & 0.7 & 0.5 & 1.6 \\
\hline $25 \%$ & - & 2.0 & 1.7 & 0.7 & 0.7 & 0.7 & 0.6 & 0.4 & 0.4 & 0.3 & 0.2 \\
\hline $10 \%$ & - & - & - & 1.2 & 0.6 & 0.4 & 0.2 & - & - & - & - \\
\hline
\end{tabular}

*weighted

Table 8B: Rates of Return on Social Security Benefits and Taxes by AIME Decile, Households with One Member 51 to 56 in 1992

\begin{tabular}{|c|c|c|c|c|c|c|c|c|c|c|c|}
\hline & \multicolumn{11}{|c|}{ Annualized Household AIME deciles: 1992 (2004 dollars) } \\
\hline & $0-5 \mathrm{~K}$ & $5-13$ & $13-21$ & $21-29$ & $29-37$ & $37-44$ & $44-51$ & $51-59$ & $59-69$ & $69+$ & All \\
\hline \multicolumn{12}{|c|}{ Rate of return percentiles } \\
\hline $90 \%$ & 6.0 & 6.5 & 5.5 & 5.2 & 5.0 & 4.5 & 4.4 & 3.9 & 3.8 & 3.2 & 5.2 \\
\hline $75 \%$ & - & 5.9 & 4.9 & 4.6 & 4.3 & 3.9 & 3.6 & 3.2 & 3.1 & 2.4 & 4.1 \\
\hline $50 \%$ & - & 5.1 & 3.9 & 3.6 & 3.3 & 3.1 & 2.6 & 2.3 & 2.0 & 1.5 & 2.7 \\
\hline $25 \%$ & & 3.2 & 2.7 & 2.3 & 2.0 & 2.0 & 1.6 & 1.2 & 0.8 & 0.5 & 1.2 \\
\hline $10 \%$ & & - & 1.5 & $\begin{array}{ll}1.1 \\
\end{array}$ & 1.0 & 1.0 & 0.8 & 0.3 & 0.2 & 0.2 & - \\
\hline
\end{tabular}

*weighted. 


\section{Robustness of Findings}

This section examines the sensitivity of differences in measured outcomes between the 2004 and 1992 cohorts to two differences between the relevant time periods in which they worked and claim benefits. First, there has been an increase in the share of households consisting of one divorced person that may affect measures of distribution and redistribution (Tamborini, Iams and Whitman, 2009). Second, there are differences in the interest rates applied to the two cohorts.

\section{Sensitivity to Changes in Family Structure}

Table 9 presents revised measures of redistribution when household weights are adjusted to hold constant the share of one person, divorced households. Specifically, the share of such households in 2004 is adjusted to the level in 1992.

As seen in Table 7, when the household distribution is not adjusted for changes in the share of single, divorced households, 7.08 percent of total benefits are redistributed. When the mix of households is standardized to control for the growth of households with a single, divorced person, the bottom row, bottom column of Table 9 suggests that 7.25 percent of total benefits are redistributed. Thus the basic findings are not very sensitive to the increase in the number of divorced households. 
Table 9: Measures of Distributions of Household Social Security Benefits and Taxes for All Age Eligible Respondents (Weights are adjusted for divorced families).

\begin{tabular}{|c|c|c|c|c|c|c|c|c|c|c|c|}
\hline & \multicolumn{11}{|c|}{ Annualized Household AIME Deciles: 2004 (2004 dollars) } \\
\hline & $0-12 \mathrm{~K}$ & $12-24$ & $24-34$ & $34-43$ & $43-53$ & $53-63$ & $65-76$ & $76-89$ & $89-105$ & $105+$ & All \\
\hline Average family lifetime taxes & $\$ 34 \mathrm{~K}$ & 91 & 146 & 187 & 234 & 286 & 330 & 382 & 445 & 565 & 270 \\
\hline Average family lifetime benefits* & $\$ 58 \mathrm{~K}$ & 142 & 195 & 224 & 270 & 325 & 340 & 385 & 412 & 447 & 280 \\
\hline $\begin{array}{l}\text { Measure of redistribution \% by which } \\
\text { benefits are increased }\end{array}$ & $60 \%$ & 49 & 25 & 15 & 8 & 7 & -2 & -4 & -13 & -24 & - \\
\hline $\begin{array}{l}\text { Share of total benefits redistributed to } \\
\text { decile }\end{array}$ & $1.05 \%$ & 2.02 & 1.63 & 1.13 & 0.73 & 0.69 & -0.28 & -0.62 & -1.88 & -4.47 & 7.25 \\
\hline
\end{tabular}

*Household benefits include benefit based on own earnings plus top-ups. 


\section{Sensitivity to Changes in the Interest Rate}

When computing outcomes for the 2004 and 1992 cohorts, different interest rates were used. The rates used for the 2004 cohort are those in place twelve years later than the interest rates used for the 1992 cohort. Interest rates are generally higher for the 1992 cohort. A higher interest rate reduces the present value of benefits and increases the present value of taxes paid when yearly values are moved to the base period. Thus if the 1992 cohort enjoyed the lower interest rates experienced by members of the 2004 cohort, the present value of their benefits as of 1992 would have been higher, and the present value of their taxes lower.

To estimate the effects of these differences in interest rates, Table 10 reports the present values calculated for the 2004 cohort (column 1) and the 1992 cohort (column 3) using the interest rates that actually applied to those cohorts. Column 2 calculates comparable values for the 1992 cohort using the interest rates that applied to the 2004 cohort. All values are taken to the base year, either 1992 or 2004 as appropriate, and are converted to 2004 dollars.

The rows of Table 10 then report the present value of taxes, the present value of benefits, and the share of total benefits redistributed among deciles. The first panel is for individuals based on own earnings. The second is for households from each cohort. Household benefits are the sum of own benefits of each spouse in married households and any spouse and survivor benefits that would accrue to the low earning spouse.

The last column of Table 10 indicates the share of the difference in the relevant value between the 1992 and 2004 cohort that is due to the interest rate. For example, take the present value of benefits to be received by households. The measured difference in benefits is $\$ 271,000$ in 2004 (from column 1) minus $\$ 209,000$ in 1992 (from column 3). The part of the difference 
from $\$ 209,000$ to $\$ 226,000$ (the value in column 2 minus the value in column 3 ) is due to the lower interest rate facing the 2004 cohort. So as reported in column 4, 27 percent of the difference in benefits is due to the difference in interest rates [(226-209)/(271 - 209)].

In the case of taxes, the higher interest rate applicable when summing up the 1992 cohort's lifetime taxes increased the base value of the tax, and caused the difference in the taxes paid by the 2004 and 1992 cohorts to be understated by just over a quarter.

These findings mean that the raw differences in present value overstate the fall in the benefit/tax ratio for Social Security between 1992 and 2004. Nevertheless, there has been a substantial decline in the value of benefits relative to taxes over the period, as indicated by the fall in the rates of return, which are not subject to the effects of changing market interest rates. Remember that whatever the implications for differences between the cohorts in benefits and taxes, the level of benefits and taxes paid by the 2004 cohort still differ in present value by only 4 percent, as shown in Table 4.

More importantly, from the perspective of this paper, the differences in redistribution measured in this paper are hardly affected by the difference in the interest rate. As seen in the last column, last row of Table 10, the measured difference in redistribution affecting each cohort is changed by only 14 percent when the interest rates are standardized.

These exercises suggest our findings are not sensitive either to the differences in the structure of families between the cohorts, or to differences in the interest rates that prevailed between the two cohorts. 
Table 10: Sensitivity of Measures of Benefits, Distribution and Redistribution to the Interest Rate Employed (Interest rates applicable to persons of the same age from the 2004 cohort are applied to benefits and taxes for members of the 1992 Cohort)

\begin{tabular}{|c|c|c|c|c|}
\hline & $\begin{array}{l}2004 \text { Cohort Using } \\
2004 \text { Interest Rates }\end{array}$ & $\begin{array}{l}1992 \text { Cohort Using } \\
2004 \text { Interest Rates }\end{array}$ & $\begin{array}{l}1992 \text { Cohort Using } \\
1992 \text { Interest Rates }\end{array}$ & $\begin{array}{l}\text { Share of 2004- } \\
1992 \text { Cohort } \\
\text { Difference Due to } \\
\text { Interest Rate }\end{array}$ \\
\hline \multicolumn{5}{|c|}{ Values for Individuals Based on Own Earnings } \\
\hline Present Value of Benefits & 135 & 110 & 102 & .24 \\
\hline Present Value of Taxes & 166 & 90 & 104 & -.23 \\
\hline Share of Total Benefits Redistributed & 11.68 & 9.19 & 9.53 & .16 \\
\hline \multicolumn{5}{|l|}{ Values for Households } \\
\hline Present Value of Benefits & 271 & 226 & 209 & .27 \\
\hline Present Value of Taxes & 260 & 145 & 170 & -.28 \\
\hline Share of Total Benefits Redistributed & 7.08 & 4.86 & 4.51 & .14 \\
\hline
\end{tabular}

All values of benefits and taxes are in thousands of 2004 dollars. 


\section{Conclusions}

This paper has measured the difference in redistribution of benefits fostered by the Social Security system between cohorts of individuals and households from the Health and Retirement Study. In summarizing our findings, a number of results may be highlighted. Comparing the 1992 and 2004 cohorts, benefits received by members of the highest AIME deciles are reduced by a greater proportional amount in 2004 than they were in 1992. The fraction of total Social Security benefits redistributed from high to low earning individuals increased from 9.5 percent for the 1992 cohort to 11.7 percent for the 2004 cohort. At the household level, the fraction of benefits redistributed from high to low earning households increased from 4.5 percent to 7.1 percent. Nevertheless, a 4.6 percentage point gap remains between the share of benefits redistributed at the individual and household levels. In sum, the 2004 Social Security system, by some measures, was somewhat more effective in redistributing benefits to low AIME households, but was still substantially less effective in redistributing benefits among households arrayed according to lifetime covered earnings than it was in redistributing benefits among individuals according to own earnings.

Looking to the future, it will not be long until data for the 2010 HRS households become available. One can expect an update of this study to indicate progress in the same direction as measured here. Women from the new, younger HRS cohort will have shown even greater attachment to the labor market. Nevertheless, the Social Security system is likely to remain less effective in redistributing benefits among families with different income than is suggested by the basic benefit formula. 
From a policy perspective, this study provides basic facts upon which to base any policy changes meant to revise the redistributive effects of the OASI system. The degree of redistribution remains quite modest at the household level. Perhaps the lack of effective redistribution has increased the popularity of the program as a source of income in retirement. That is an issue for policy makers to wrestle with. They must decide whether they are happy with the rather modest level of redistribution of Social Security benefits at the household level, or whether they would prefer a system that is more, or less, redistributive. 


\section{References:}

Biggs, Andrew G., Mark Sarney and Christoper R. Tamborini. 2009. “A Progressivity Index for Social Security. Social Security Issue Paper No 2009-1. January.

Coe, Norma B., Zhenya Karamcheva, Richard W. Kopcke and Alicia Munnell. 2011. "How Does the Personal Income Tax Affect the Progressivity of OASI Benefits?" Paper presented at the meeting of the Retirement Research Consortium, Washington, D.C.

Coronado, Julia Lynn, Don Fullerton and Thomas Glass. 2000. "The Progressivity of Social Security". NBER Working Paper 7520.

Goda, Gopi Shah, John B. Shoven and Sita Nataraj Slavov. 2011. "Differential Mortality by Income and Social Security Progressivity". In David A. Wise, Editor, Explorations in the Economics of Aging. Chicago: University of Chicago Press for NBER: 189-204.

Gustman, Alan L. and Thomas L. Steinmeier. 2001. "How Effective Is Redistribution Under The Social Security Benefit Formula?" Journal of Public Economics 82 (1): 1-28.

Gustman, Alan L., Thomas L. Steinmeier and Nahid Tabatabai. 2010. "The Growth in Social Security Benefits Among the Retirement Age Population from Increases in the Cap on Covered Earnings". NBER Working Paper 16501.

Harris, Amy Rehder and John Sabelhaus. 2005. "How Does Differential Mortality Affect Social Security Finances and Progressivity?" Washington, D.C.: Congressional Budget Office, Working Paper.

Hurd, Michael. 2011. Comment on "Differential Mortality by Income and Social Security Progressivity". In David A. Wise, Editor, Explorations in the Economics of Aging. Chicago: University of Chicago Press for NBER: 205-208.

Iams, Howard M., John W.R. Phillips, Kristen Robinson, Lionel Deang and Irena Sushi. 2008.

"Cohort Changes in the Retirement Resources of Older Women". Social Security Bulletin 68(4): 1 - 13.

Liebman, Jeffrey B. 2002. "Redistribution in the Current U.S. Social Security System". In

Martin Feldstein and Jeffrey B. Liebman, editors. The Distributional Aspects of Social Security and Social Security Reform. Chicago: University of Chicago Press: $11-48$.

Smith, Karen, Eric Toder, and Howard Iams. 2003. "Lifetime distributional effects of Social Security retirement benefits". Social Security Bulletin 65(1): 33-61.

Steuerle, C.Eugene and Jon M. Bakija. 1994. Retooling Social Security for the 21st Century: Right and Wrong Approaches to Reform. Urban Institute. Washington, D.C.

Tamborini, Christopher R., Howard M. Iams and Kevin Whitman. 2009. "Marital History, Race, and Social Security Spouse and Widow Benefit Eligibility in the United States". Research on Aging 31(5): 577-605.

U.S. Social Security Administration. 2010. "The 2010 Annual Report of the Board of Trustees of the Federal Old-Age and Survivors Insurance and Disability Insurance Trust Funds". Washington, D.C.: U.S. Social Security Administration. 